\title{
Our best friends are Republicans
}

\section{That the Republican National Committee has had a hand in choosing members of a scientific advisory committee of the US Department of the Interior threatens the effectiveness of the administration.}

So many blacklists of government committee members have appeared in Washington in the past few weeks that nobody whose credentials have been disparaged need be despondent. Indeed, so many honourable people have been blackballed, most notoriously in the Environmental Protection Agency hit-list made public a few weeks ago (see Nature 10 March, p.95), that being known as a person of whom the administration approves may be a greater cause of embarrassment. Many will recall Groucho Marx's celebrated remark that he would not wish to belong to a club that would have him as a member. But the revelation that the new membership of a not particularly important advisory committee of the US Department of the Interior has been vetted by of ficials of the Republican Party raises issues of principle whose importance the administration seems naively to have overlooked. The credibility of the advice it is given on technical questions, if it carries on like this, will undermine the capacity of its successors to govern the United States effectively.

The convention in the United States that a new president appoints not merely cabinet officers but senior members of the civil service from his own political party is well established if imperfectly understood outside the United States. Although the practice has often led to questionable pork-barrel appointments, the staid European opinion that the civil service should rise above party politics is not as easily defensible as it seems. The argument that cabinet officers can be effective only when their policies are supported by their senior civil servants also has force. But hitherto, even US presidents have excluded some parts of the government from the rule that they must be surrounded by their political friends. Thus it has been supposed that the party allegiance (if any) of the director of the National Science Foundation would be irrelevant to his or her tenure of office and, fair play, the Reagan Administration lived peaceably with President Carter's Democratic incumbent until Dr John Slaughter resigned at the end of last year.

What the administration has failed to appreciate is that appointments to advisory committees must fall in a different category. Especially when the subject on which advice is sought is technical, the numbers of people whose expertise qualifies them to give sound advice is almost certain to be limited. Moreover, many of the questions on which the administration seeks advice, often at the insistence of Congress, are strictly above and beyond politics. This is manifestly the case with the Interior Department committee whose membership has now been restricted to registered Republicans. Indeed, to expect that Democrat and Republican geophysicists would differ in their advice on research projects supported by the Department of the Interior is tantamount to supposing that Democrats and Republicans differ from each other not merely on questions such as the role of welfare in a modern society but on theories of the origin of the Earth's crust.

Even when questions with more immediate political implications are to be decided, however, there must be grave doubts whether even the administration's interests are best served by advice prepackaged to give no offence. In the environmental field, for example, this administration is plainly impatient with the network of regulatory legislation that has accumulated, and would have a cogent argument if only it would put its case more temperately (see Nature 17 March, p.197). But by no stretch of the imagination can it be supposed that all environmental hazards can be rendered harmless because the administration wishes that were the case. Dioxin, for example, will remain toxic even in very small amounts, and the administration will have to discharge its legal responsibility for seeing that it is not scattered liberally throughout the United States. Politically, the government will be in serious trouble if it takes too lax a view of how tolerable limits of contamination should be decided. But packing the committees that advise on these questions with yes-men is to court just that risk. A few "snail-darter types", as a now-sacked official of the Environmental Protection Agency called environmentalists, may be politically necessary.

A more sensitive government would have learned this from its experience even in the past few months. When the administration was wrestling last year with the question how and where to base the MX missile, a letter leaked to the newspapers suggested that the chairman of a technical advisory committee, $\mathrm{Dr}$ C.H. Townes, disagreed with the Pentagon's dense-pack solution. The administration overrode that unwelcome advice, and then for its pains got egg on its face when it went to Congress for the money. This is the inevitably consequence of ignoring honestly-given advice, whether its authors are Republicans or Democrats. And it will not help to launder committees so as to ensure that the advice they give is always welcome. One result will be to ensure that mistakes are made. Another will be that technical people, usually willing in the national interest to serve presidents for whom they did not vote, will flatly refuse to serve in any capacity.

\section{Freeing the manipulators}

\section{The committees set up to regulate genetic} manipulation should be stopped.

DISPENSE with the regulatory committees set up in the past ten years to superintend recombinant-DNA research. That is the simple answer to the central question in the British Government's consultative document published this week (see page 467) - what should be the future of the Genetic Manipulation Advisory Group (GMAG) set up to license recombinant-DNA research projects? The same comment applies to the report Splicing Life, put out a few weeks ago in the United States by the President's Commission on Ethical Problems in Medicine (which has itself now gone out of business - see page 468). The regulatory committees, which for a time in the late 1970 s were springing up more quickly than the use of restriction enzymes was increasing, have done an invaluable job. But now there is almost nothing left for them to do.

When in 1974 Professor Paul Berg of Stanford University blew the first whistle, pointing out that experiments with the simian virus SV40 loaded with foreign pieces of DNA might endanger people's health, there was good reason why professional people, governments and the general public should have taken fright. The voluntary moratorium on experiments that followed remains without precedent in research. So, too, does the willingness of the research community to fall in with the requirement afterwards imposed that experiments should be specified in advance and carried out only when approved.

This regulatory apparatus was at first designed for two purposes - to protect people's health (that of laboratory workers included) and to assure the general public that progress in this 